Nippon Suisan Gakkaishi $\quad$ 73(2), 310-312 (2007)

\title{
特集 水産微生物のリアルタイムモニタリング
}

\section{魚類病原性ビブリオ菌のモニタリング}

\author{
澤辺智雄, $*$ 福井洋 平 \\ 北海道大学大学院水産科学研究院海洋生物工学分野
}

Monitoring of fish-pathogenic vibrios

Tomoo SAWABE* AND YouheI FUKUI

\begin{abstract}
Laboratory of Marine Biotechnology and Microbiology, Faculty of Fisheries Sciences, Hokkaido University, Hakodate, Hokkaido 041-8611, Japan
\end{abstract}

\section{1. はじめに}

1831 年から 1866 年にかけて, 4 度にわたり, イギリ スでコレラが流行し，死者は 14 万人に達した。1,2) コレ ラの原因は, Vibrio choleraeである。John Snowによっ て描かれた「Broad streetの地図」に集約されている疫 学手法 ${ }^{1,2}$ は, 「病原体と病気の広がり方」を的確に判断 したものであり，ビブリオ菌のモニタリングの原型をな すといってよい。これは, 水産分野で問題となるビブリ 才病の制圧に抢いても, 今なお，学ぶべきところが多 い。我々の時代では, 新しい細菌の特異検出技術が進展 し, 魚病の診断だけでなく, 感染症を引き起こすビブリ 才菌の環境での挙動を逐次把握することが可能となって きた。本稿では, 水産分野で問題となっている魚類病原 性ビブリオ菌のモニタリング研究の現状と課題を紹介す る。

\section{2. ビブリオ病原因細菌のモニタリングの現状}

ビブリオ菌は, 汽水域や沿岸海域及び海産動物の消化 管に生息している。分類学的にはビブリオ科に属し, 現 在までに 5 属 80 種が知られている。 ${ }^{3-5}$ 魚介類に対し て，ビブリオ病を引き起こすと報告されている種は Photobacterium damselae (damselae と piscicida の両亜 種), $V$. alginolyticus, $V$. anguillarum, $V$. cholerae, $V$. fischeri, V. furnissii, V. harveyi, V. ichthyoenteri, V. logei, $V$. mediterranei (V. shiloi), V. ordalii, V. pelagius, $V$. salmonicida, V. splendidus, V. vulnificus 及び V. penaeici$d a$ である。6,7) 産業被害が多いか，または表現形質や免 疫反応などを行なっても近縁種との区別が困難なビブリ オ菌, 例えば $V$. anguillarum, V. harveyi, V. penaeicida, V. tapetis では, 遺伝子増幅技術を基礎とする特異検出 法が構築されている(表 1 )。これらの特異検出法は, 魚病診断や魚介類の病原菌保持状況のサーベイランスに 使用される頻度が高い。しかし, 環境中の菌数を定量的 に測定した研究例は思ったより少ない。中でも, リアル
タイム定量 PCR 法が検討され，リアルタイムモニタリ ングが可能なビブリオ病原因細菌は, V. penaeicid $a^{7)}$ と $V$. harveyi（福井，澤辺，投稿中）の 2 種である。

\section{3. アワビ養殖環境下に生息する $V$. harveyi モニタリ} ング

V. harveyi は, 様々な魚介類に病原性を示すことが知 られている。8) 特に, 東南アジアや南米のエビ養殖場で は, V. harveyi や発光性ビブリオ菌による大量死が観察 され，エビ生産事業に経済的打撃を与えている。9-12) ま た，日本の北海道内のエゾアワビ養殖施設では， 1980 年代以降, 水温が $20^{\circ} \mathrm{C}$ を超える高水温期に, V. har veyi 感染を原因とする大量死が発生している（澤辺ら， 投稿中)。この大量死は突発的に起きるため, アワビ養 殖場に抢ける大量死の発生予測が難しい。アワビには抗 生物質投与は認められていないため, この大量死発生の 予兆を把握するためにも, V. harveyi 菌数の変化を感度 良くモニタリングし，1 日以内で解析できる迅速性をも ち合わせた簡易な手法の構築が望をれている。

筆者らは, $V$. harveyi の特異検出に有効なコロニー PCR 法とリアルタイム定量 PCR 法を開発し，それらを 養殖施設に抢ける $V$. harveyi の生態解明, さらには本 疾病の発生予測に利用すべく研究を進めている。

コロニーPCR 法では, 一週間間隔で V. harveyi 菌数 の変動を解析することが可能な方法の構築を目指し た。13) データベースに登録されているV. harveyi 標準株 の $16 \mathrm{~S}$ rRNA 遺伝子塩基配列には誤読領域があると報 告されている。 ${ }^{14)} こ の$ 領域の一部をVHARF-VHARR プライマーセットの配列に用いた。このプライマーセッ 卜と特異検出のために至適化した条件下に扔いて， $V$. harveyi の培養菌体を直接 PCR の鋳型としてもその特異 性に変化はなく, 環境試料中の細菌の培養から始めて, 3 日以内に V. harveyi を検出できるコロニーPCR 法が 完成した。本法を利用して, アワビ養殖環境水から分離

* Tel. : 81-138-40-5570. Fax : 81-138-40-5570. Email : sawabe@fish.hokudai.ac.jp 
表 1 ビブリオ病原因細菌の特異検出法とモニタリングへの応用例

\begin{tabular}{|c|c|c|c|c|}
\hline 標的種 & 感染動物 & 方 法 & $\begin{array}{l}\text { モニタリング } \\
\text { ヘの応用例* }\end{array}$ & 参考文献 \\
\hline V. anguillarum \& V. ordalii & ウナギ・サケ・アユなど & $\begin{array}{l}\text { Colony hybridization } \\
\text { (16S rRNA) }\end{array}$ & あり & $\begin{array}{l}\text { Martinez-Picado et al., } \\
1994^{17)}, 1996^{18)}\end{array}$ \\
\hline $\begin{array}{l}\text { V. anguillarum (ヘモリジン } \\
\text { 産生株) }\end{array}$ & サケ・アユなど & $\begin{array}{l}\text { Multiprex-PCR (hetoxR, } \\
\text { tdh, \& trh) }\end{array}$ & なし & Rodkhum et al., 2006 19 ) \\
\hline V. harveyi & $\begin{array}{l}\text { サメ·ヒラメ·エビ・アワ } \\
\text { ビなど }\end{array}$ & $\mathrm{PCR}($ toxR $)$ & なし & Pang et al., 2006 20$)$ \\
\hline$V$. harveyi & $\begin{array}{l}\text { サメ·ヒラメ·エビ・アワ } \\
\text { ビなど }\end{array}$ & MPN-PCR $(g y r B)$ & あり & Thaithongnum et al., 2006 21$)$ \\
\hline$V$. harveyi & $\begin{array}{l}\text { サメ·ヒラメ·エビ・アワ } \\
\text { ビなど }\end{array}$ & Colony-PCR (16S rRNA) & あり & Fukui \& Sawabe, 200713) \\
\hline$V$. harveyi & $\begin{array}{l}\text { サメ·ヒラメ·エビ・アワ } \\
\text { ビなど }\end{array}$ & $\begin{array}{l}\text { Real-time PCR } \\
(16 \mathrm{~S} \text { rRNA) }\end{array}$ & あり & 福井, 澤辺, 投稿中 \\
\hline$V$. mediterranei ( $V$. shiloi) & サンゴ & Hybridization (16S rRNA) & なし & Sussman et al., 200322) \\
\hline$V$. parahaemolyticus & ハタ・エビ・アワビなど & $\mathrm{PCR}($ toxR $)$ & なし & Kim et al., 199923) \\
\hline $\begin{array}{l}\text { V. parahaemolyticus } \\
\text { (病原株) }\end{array}$ & ハタ・エビ・アワビなど & Real-time PCR $(t d h)$ & あり & Blackstone et al., 200324) \\
\hline V. tapetis & アサリ & $\begin{array}{l}\text { PCR \& Hybridization } \\
\text { (16S rRNA) }\end{array}$ & あり & Paillard et al., 2006 25) \\
\hline$V$. penaeicida & エビ & $\begin{array}{l}\text { Real-time PCR } \\
\text { (16S rRNA) }\end{array}$ & あり & $\begin{array}{l}\text { Saulnier et al., 2000; Goarant } \\
\text { \& Merien, 2006 } 26)\end{array}$ \\
\hline P. damselae & ブリ・スズキなど & $\begin{array}{l}\text { Multiprex-PCR (16S rRNA } \\
\text { \& ureC) }\end{array}$ & なし & Osorio et al., 200027) \\
\hline
\end{tabular}

* 報告手法を用いて, 環境中の細菌の定量解析がなされている場合, モニタリングへの応用例が「あり」とした。

された株は, 複数のハウスキーピング遺伝子解析でも V. harveyi と同定され，本法の特異性の高さが証明され た。水温の上昇とともに, 沿岸域で $V$. harveyi 菌数が 増加し, 養殖場で使用されている飼育用水を介してアワ ビに感染する機会が増加していることも明らかになりは じめた。

一方, リアルタイム定量 PCR 法では, 一日間隔で $V$. harveyi 菌数の変動解析が可能な手法の構築を目指し た。リアルタイム定量 PCR 法のプライマー及びプロー ブには， V. harveyiに特異性の高い領域を新たに見いだ し，RTVHAF - RTVHARプライマーセット及び RTVHA TaqMan プローブを設計した。このプローブ とプライマーセットは, 供試した 20 種のビブリオ属細 菌の中で，V. harveyi を特異的に検出できた。

リアルタイム定量 PCR 法を用いたモニタリングを可 能にするための重要なステップは, 環境試料から鋳型 DNA を抽出するステップである。様々な生理状態の菌 体から効率よくDNA を抽出でき，また短時間で処理が 可能で, かつ操作段階は少ないことが求められる。そこ で, 自然海水から V. harveyiを高感度に検出できる DNA 抽出法を検討した。現場で多検体処理することも 考慮し, 鋳型 DNA を調製する出発材料は, $1 \mathrm{~mL}$ の海 水試料とした。 $V$. harveyiの新鮮培養菌体を $10^{6}$ から $10^{\circ} \mathrm{CFU} / \mathrm{mL}$ になるよう滅菌海水に添加し, その $1 \mathrm{~mL}$ を遠心分離で集菌し, 数種の抽出法を使い, 鋳型 DNA を調製した。その結果, レジン法が $100 \mathrm{CFU} / \mathrm{mL}$ と高
い検出限界值を得ることが明らかとなった。レジン法 は, DNAの分解を触媒する金属イオンを除去すること から，PCR を阻害する物質を多く含む試料には効果が あることが明らかにされており, ${ }^{15)} V$. vulnificusのリア ルタイム定量 PCR 検出の鋳型 DNA 調製でも適する方 法であることが報告されている。1)なお，V. penaeicida のリアルタイム定量 PCR 法では, 市販の簡易 DNA 精 製キットが効果的であることも報告されている。15)

2005 年のアワビ養殖施設における大量死発生前後 に, この定量的 PCR 法を用いて, 菌数の変動を調べ た。施設沿岸の海水, 飼育用水, 及び飼育水槽水を採取 し, 定量的 PCR に供試した。V. harveyi の培養計数值 は, 前述の $V$. harveyi 特異検出コロニー PCR 法により 算出した結果, エゾアワビ大量死が発生した時に, 飼育 水槽水では約 $10^{2} \mathrm{CFU} / \mathrm{mL}$ の . harveyi が検出され た。この值は培養計数值とほぼ同程度の菌数であった。

\section{4. 今後の課題}

脊椎動物から無脊椎動物むで幅広く海洋動物の大量死 を引き起こすことが報告され, 海洋動物病原ビブリオと 認識され始めた $V$. harveyi 法やリアルタイム定量 PCR 法を用いたビブリオ病原因 細菌のモニタリングの可能性を紹介した。この方法を用 いることにより, 自然環境下のビブリオ菌の数を 5 時 間以内に定量することが可能である。実際にこの方法を 使い, 2003 年から V. harveyi 菌数のモニタリングを行 い, 自然界でこの細菌が増加する環境条件や大量死の発 
生を引き起こす菌数の閾值が解明されつつある。

Snow がコレラ菌で污染された井戸の閉鎖を決断し， この措置がコレラの流行を終息に向かわせたような成果 にまでは至っていないが, 自然界のビブリオ病原因細菌 の数を定量的に理解できるようにはなってきた。特に, 本稿で紹介したリアルタイム定量 PCR 法は, 試水がわ ずか $1 \mathrm{~mL}$ で斉み, かつその検出限界は $10^{2} \mathrm{CFU} / \mathrm{mL}$ である。これに供試する試料の調製は 1 時間以内であ ることから, 現場対応 (On-Site) のリアルタイム定量 PCR に向いている。アワビ大量死が発生した時のよう にV. harveyi 菌数が $10^{2} \mathrm{CFU} / \mathrm{mL}$ 程度にまで増加した 水試料であれば, 定量が可能である。今後は, 大量死の 発生前の $V$. harveyi 菌数の増加をモニタリングできる まで感度を上げることが課題である。将来，このような モニタリング技術が，水温データロガーのように海域に 設置しながら簡単に測定できるまで革新を遂げることを 願いながら，技術精度の向上に配慮していかなければな らない。

\section{文献}

1) Snow SJ. Sutherland, Snow and water: the transmission of cholera in the nineteenth century. Int. J. Epidemiol. 2002; 31: 908-911.

2) Collins CH. John Snow-'On the mode of communication of Cholera'. Med. Sci. Histrory 2003; 19: 12-19.

3) Park YD, Baik KS, Seong CN, Bae KS, Kim S, Chun J. Photobacterium ganghwense sp. nov., a halophilic bacterium isolated from sea water. Int. J. Syst. Evol. Microbiol. 2006; 56: 745-749.

4) Thompson FL, Iida T, Swings J. Biodiversity of vibrios. Microbiol. Mol. Biol. Rev. 2004; 68: 403-431.

5) Thompson FL, Swings J. Taxonomy of the vibrios. In: Thompson FL, Austin B, Swings J. (eds). The Biology of Vibrios. ASM Press, Washington, D. C. 2006; 29-43.

6) Austin B, Austin DA. Characteristics of the pathogens: Gram-negative bacteria, Vibrionaceae representatives. In: Austin B, Austin DA. (eds). Bacterial fish pathogens: disease of farmed and wild fish, 3rd edition. Springer-Verlag, Berlin. 1999; 28-32.

7) Goarant C, Merien F. Quantification of Vibrio penaeicida, the etiological agent of syndrome 93 in New Caledonian shrimp, by real-time PCR using SYBR Green I chemistry. J. Microbiol. Methods 2006; 67: 27-35.

8) Austin B, Zhang XH. Vibrio harveyi: a significant pathogen of marine vertebrates and invertebrates. Let. Appl. Microbiol. 2006; 43: 119-124.

9) Alvarez JD, Austin B, Alvarez AM, Reyes H. Vibrio harveyi: a pathogen of penaeid shrimps and fish in Venezuela. J. Fish Dis. 1998; 21: 313-316.

10) Lavilla-Pitogo CR, Baticados MCL, Cruz-Lacierda ER, Pena LD. Occurrence of luminous bacterial disease of Penaeus monodon larvae in the Philippines. Aquaculture 1990; 91: 1-13.

11) Prayitno SB, Latchford JW. Experimental infection of crustaceans with luminous bacteria related to Photobacterium and Vibrio. Effect of salinity and $\mathrm{pH}$ on infectiosity. Aquaculture 1995; 132: 105-112.
12) Robertson PAW, Xu HS, Austin B. An enzyme-linked immunosorbent assay (ELISA) for detection of Vibrio harveyi in penaeid shrimp and water. J. Microbiol. Methods 1998; 34: 31-39.

13) Fukui Y, Sawabe T. Improved one-step colony PCR detection of Vibrio harveyi. Microb. Environ. 2007; (In press).

14) Gauger, EJ, Gómez-Chiarri M. 16S ribosomal DNA sequencing confirms the synonymy of Vibrio harveyi and $V$. carchariae. Dis. Aquat. Org. 2002; 52: 39-46.

15) Walsh PS, Metzger DA, Higuchi R. Chelex100 as a medium for simple extraction of DNA for PCR-based typing from forensic material. Biotech. 1991; 10: 506-513.

16) Panicker G, Micheal ML, Bej AK. Rapid detection of Vibrio vulnificus in shellfish and gulf of Mexico water by real-time PCR. Appl. Environ. Microbiol. 2004; 70: 498507.

17) Martinez-Picado J, Branch AR, Jofre J. Rapid detection and identification of Vibrio anguillarum by using a specific oligonucleotide probe complementary to $16 \mathrm{~S}$ rRNA. Appl. Environ. Microbiol. 1994; 60: 732-737.

18) Martinez-Picado J, Alsina M, Branch AR, Cerda M, Jofre J. Species-specific detection of Vibrio anguillarum in marine aquaculture environments by selective culture and DNA hybridization. Appl. Environ. Microbiol. 1996; 62: 443-449.

19) Rodkhum C, Hirano I, Crosa JH, Aoki T. Multiplex PCR for simultaneous detection of five virulence hemolysin genes in Vibrio anguillarum. J. Microbiol. Methods 2006; 65: $612-618$.

20) Pang L, Zhang XH, Zhong Y, Chen J, Li Y, Austin B. Identification of Vibrio harveyi using PCR amplification of the toxR gene. Let. Appl. Microbiol. 2006; 43: 249-255.

21) Thaithongnum S, Ratanama P, Weeradechapol K, Sulhoom A, Vuddhakul V. Detection of Vibrio harveyi in shrimp postlarvae and hatchery tank water by most probable number technique with PCR. Aquaculture 2006; 261: $1-9$.

22) Sussman M, Loya Y, Fine M, Rosenberg E. The marine fireworm Hermodice carunculata is a winter reservoir and spring-summer vector for the coral-bleaching pathogen Vibrio shiloi. Environ. Microbiol. 2003; 5: 250-255.

23) Kim YB, Okuda J, Matumto C, Takahashi N, Hashimoto $\mathrm{S}$, Nishibuchi M. Identification of Vibrio parahaemolyticus strains at species level by PCR targeted to the tox $R$ gene. J. Clin. Microbiol. 1999; 37: 1173-1177.

24) Blackstone GM, Nordstrom JL, Vickery MCL, Browen MD, Meyer RF, Depaola A. Development of pathogenic Vibrio parahaemolyticus in oyster enrichments by real time PCR. J. Microbiol. Methods 2003; 53: 149-155.

25) Paillard C, Gausson S, Nicolas LJ, Pennec JP, Haras D. Molecular identification of Vibrio tapetis, the causative agent of the brown ring disease of Ruditapes philippinarum. Aquaculture 2006; 253: 25-38.

26) Saulnier D, Avarre JC, Moullac GL, Ansquer D, Levy P, Vonau V. Rapid and sensitive PCR detection of Vibrio penaeicida, the putative etiological agent of syndrome 93 in New Caledonia. J. Microbiol. Methods 2000; 40: 109115.

27) Osorio CR, Toranzo AE, Romalde JL, Barja JL. Multiplex PCR assay for ureC and 16S rRNA genes clearly discriminates between both subspecies of Photobacterium damselae. Dis. Aquat. Org. 2000; 40: 177-183. 